\title{
INFORMATION FLOW BETWEEN THE US DOLLAR-RUPIAH EXCHANGE RATE
}

\author{
Wee-Yeap Lau* and Tien-Ming Yip** \\ ${ }^{*}$ Corresponding author. Faculty of Economics and Administration, University of Malaya, Kuala Lumpur. \\ Email:wylau@um.edu.my \\ ${ }^{* *}$ Faculty of Economics and Administration, University of Malaya, Kuala Lumpur.
}

\begin{abstract}
This study investigates the information flow between non-deliverable forward (NDF), spot, and forward US dollar-rupiah exchange rates during the post-Quantitative Easing (QE) period. Our results show a unidirectional information flow from NDF to the spot and forward rates in the post-QE period. We also find that the Indonesian government securities (IGS) played a vital role during the QE period, while international reserves preceded the US dollar-rupiah spot, forward, and NDF exchange rates post-QE. Hence, international reserves became an important policy variable in managing the currency value. Our finding redefines the role of IGS as a policy tool. As a policy suggestion, the Bank Indonesia should maintain a sufficient amount of foreign reserves to mitigate foreign exchange risks of the rupiah.
\end{abstract}

Keywords: Spot; Forward; Non-deliverable forward; Quantitative easing; Rupiah; Exchange rates. JEL Classifications: C51; F31; G13.

Article history:

Received : June 13, 2019

Revised : March 21, 2020

Accepted : July 21, 2020

Available online : October 30, 2020

https://doi.org/10.21098/bemp.v23i3.918 


\section{INTRODUCTION}

In the aftermath of the 2008-09 Global Financial Crisis, the US Federal Reserve engaged in an unconventional monetary policy to stimulate the US economy through a large-scale asset purchase (LSAP) program also known as the QE policy. The QE policy, led to an exchange rate appreciation, a reduction in long-term bond yields, a stock market boom, and an inflow of foreign capital into emerging economies (Ahmed and Zlate, 2014; Chatterjee and Park, 2018).

The literature (Bauer and Neely, 2014; Neely, 2015; Bhattarai and Neely, 2016; Fratzscher et al., 2016; Alpanda and Kabaca, 2019) finds that the QE policy has a positive international spillover effect on emerging economies. However, in a study by Bhattarai et al. (2018), five countries (Brazil, India, Indonesia, Turkey, and South Africa) collectively known as the "Fragile Five", were found to be vulnerable to the shock from US monetary policy.

As the US Federal Reserve announced the end of QE program, emerging economies started to experience the Taper Tantrum beginning from the end of 2013. This was followed by a prolonged period of uncertainty in the stock market and interest rates in emerging economies (Ooi and Lau, 2020). For example, the Morgan Stanley Capital International (MSCI) Emerging Markets Index entered a bear market in early September 2015, followed by a drop in the benchmark index of emerging currencies. This phenomenon was the direct result of the Taper Tantrum and QE Exit (Anstey and Miller, 2018).

The expectation of a spike in the US federal fund rate caused the US dollar (henceforth "dollar") to gain upward momentum. At the same time, the Indonesian rupiah (IDR) touched a 17-year low and recorded IDR 13,570 per dollar on 11 August 2015 (Indonesia Investments, 2015a). Figure 1 shows that the IDR depreciated substantially in the post- QE period.

Figure 1.

The Trend of USD to IDR

This figure shows the trend of USD to IDR exchange rate.

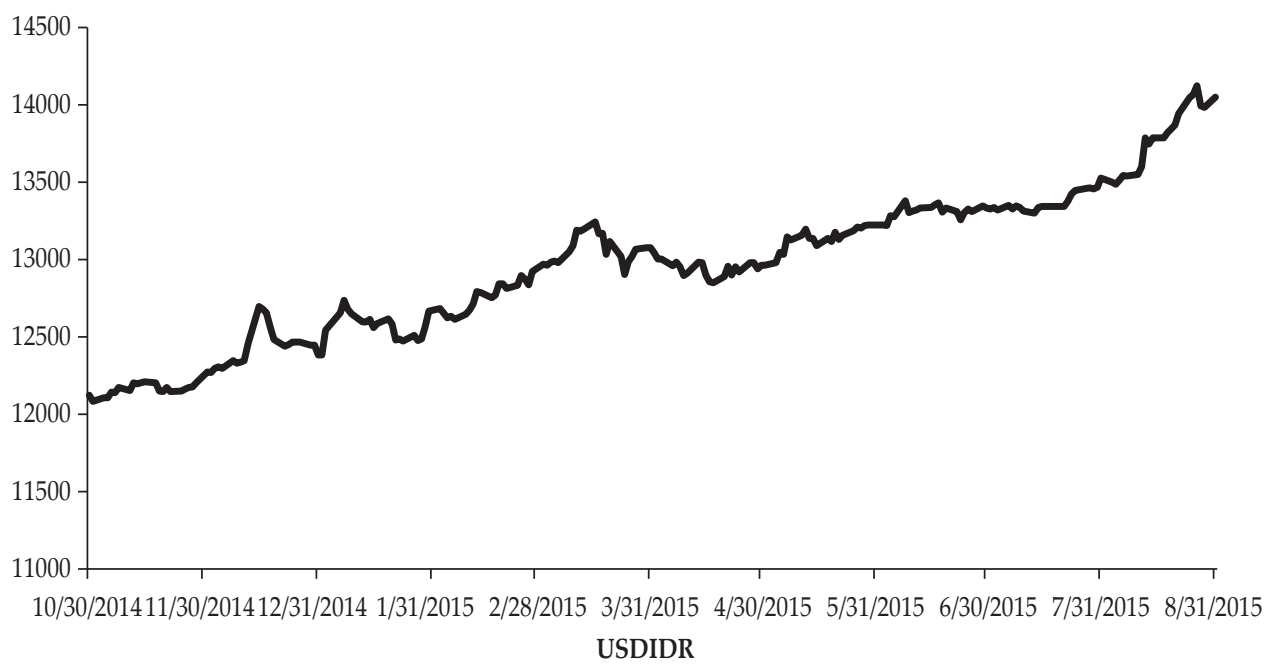

Source: Reuters 
While external factors, such as the capital outflow, caused the decline of the IDR, the activities of offshore NDF have also been perceived as one of the causes (Ren, 2015). Nangoy (2018) reported that Bank Indonesia (BI) planned to issue regulatory measures that would permit banks to trade NDFs in the domestic currency market. The new measure aims at stabilizing the IDR, which lost around 9\% vis-a-vis the dollar in 2018 have re-ignited concerns about capital outflows (Nangoy, 2018). The BI aimed to bring sizeable speculative activity in the NDF markets onshore and under its immediate purview (Nangoy, 2018).

The theoretical underpinning of the forward exchange contract is the interest rate parity condition, which explains the relationship between two currency's interest rate and current spot exchange rate. In the presence of convertibility restriction on the IDR, investors will use NDFs as a substitution for a forward contract to hedge against the restricted currency. Therefore, changes in the NDF rate is expected to affect the spot exchange rate. Empirically, studies by Park (2001), Guru (2009), Cadarajat and Lubis (2012), and Lei and Yulan (2016) support the view that changes in the NDF rate would influence the spot and forward exchange rates. In summary, there exists information flow (or Granger causality) and volatility spillover from NDF to spot and forward exchange rates.

For Indonesia, Cadarajat and Lubis (2012) study the information transmission between offshore and onshore rupiah currency markets from 2008 to 2011. However, their study has some limitations: First, their study examines the interaction between NDF and spot rate and NDF and forward exchange rate in the pre- and post-Global Financial Crisis period. However, their findings may not be generalized to the period of US QE, given that both events have different impacts on the Indonesian economy. The former is found to have a limited impact on the Indonesian economy due to the appropriate policy responses from both the BI and the Indonesian government (Basri and Rahardja, 2010), while the latter has triggered capital outflow from Indonesia, causing the USD/IDR spot rate to record a 17-year low value. Second, their study does not explore the connection between the exchange rate and other financial variables. This is important as it would provide direction to policy makers on the sources of NDF, spot, and forward exchange rate movements.

Accordingly, our paper aims to fill these gaps by studying the relationship between the spot, forward, and NDF markets and other economic variables, such as government bond yields and international reserves. Most importantly, this study compares the impact of the US QE policy on the spot, forward, and NDF markets.

Based on a vector autoregression (VAR) model, we empirically demonstrate the following. First, there is unidirectional causality running from: (a) NDF to the spot market, and (b) NDF to the forward dollar-rupiah exchange rate in the postQE period. Moreover, NDF is found to exert a higher depreciation pressure on the dollar-rupiah spot and the forward exchange rate in the post-QE period. Second, international reserves are found to precede the dollar-rupiah spot, forward and NDF exchange rates in the post-QE period. Third, the results are robust to different model specifications and estimation methods.

This study contributes to the literature on two fronts. First, it reveals the potential effect of NDF and US QE on the dollar-rupiah rate. Since NDF is found to 
exert a greater depreciation impact on the spot and forward exchange rates in the post-QE period, an appropriate stabilizing policy should be implemented by the $\mathrm{BI}$ to mitigate the depreciation effect of NDF. Second, this study shows that foreign reserves are the key to stabilizing the rupiah from a higher depreciation pressure in the post-QE period. Therefore, the BI should closely monitor international reserves to improve investors' confidence in the rupiah.

The remainder of the paper is organised as follows. Section II reviews the existing theoretical framework. Section III discusses the data and models. Section IV shows the empirical results. Lastly, Section V concludes the paper.

\section{THEORETICAL FRAMEWORK}

The study develops a conceptual framework to examine the role of NDF in the Indonesian currency markets in the post-QE period. Notably, we address the question of whether the NDF precedes the spot and forward exchange rates in the post-QE period. Hence, it is hypothesized that:

H1: During the post-QE period, NDF influences the dollar-rupiah spot exchange rate.

H2: During the post-QE period, NDF influences the dollar-rupiah forward exchange rate.

Theoretically, the price of a forward foreign exchange contract is determined by the interest rate parity condition in which equivalent return over a particular period is based on two currency's interest rate and the current spot exchange rate (Baba and Packer, 2009; Della Corte et al., 2011; Ahmad et al., 2012; Cadarajat and Lubis, 2012; and Wang et al., 2014). Hence, the interest rate differential between the two currencies would determine the forward premium. Generally, the covered interest rate parity condition holds true when there is no arbitrage condition between onshore and offshore currency markets in the absence of capital controls (Wang et al., 2014). Therefore, the relationship between the onshore and offshore markets absent capital controls can be drawn from covered interest parity as:

$$
F=\frac{1+r}{1+r^{u s}}
$$

where $F$ is the forward rate, $S$ is the spot rate, $r$ is the interest rate of the home currency and $r^{\text {uns }}$ is the dollar interest rate. However, when some forms of capital control and currency convertibility restrictions exist, non-residents may be restricted from full access to onshore currency markets. Hence, NDF serves as a substitute for the forward rate (Cadarajat and Lubis, 2012) as follows:

$$
N D F=\frac{1+r}{1+r^{u s}}
$$

Therefore, in the presence of convertibility restrictions in some of the emerging economies' currency markets, investors would use the NDF as a substitute for the forward contract to hedge against the restricted currencies, especially during capital outflow episodes. The least restrictive environment of NDF market incorporates a substantial set of information into currency exchange markets, suggesting the 
greater extent to which NDF prices would reflect the spot and forward exchange prices (Kong and Shao, 2010; Maziad and Kang, 2012; and Wang et al., 2014).

From the Indonesian perspective, the QE exit period was characterized by capital outflows. Given the convertibility restrictions in the rupiah market, investors would engage in NDF contracts to hedge against currency uncertainty. Hence, it is expected that the offshore NDF dollar-rupiah exchange rate dedicates the rate on the spot and forward markets, as stated in hypotheses 1 and 2, respectively.

Next, we incorporate international reserves into the model to examine the information flow between foreign reserves and the rupiah in the post-QE period. International reserves are imperative in explaining the movement of the rupiah. As such, foreign reserves have been the backbone of the BI in stabilising the dollarrupiah exchange rate following the depreciation pressures in the post-QE period (Indonesia Investments, 2015b). Hence, we hypothesize that:

H3: During the post-QE period, international reserves influence the dollar-rupiah spot exchange rate.

H4: During the post-QE period, international reserves influence the dollar-rupiah forward exchange rate.

H5: During the post-QE period, international reserves influence the dollar-rupiah NDF exchange rate.

Generally, central bank interventions in the foreign exchange market can be classified into sterilised interventions, which do not affect the money supply, and non-sterilized interventions, which do (Mishkin, 2016). Theoretically, sterilised interventions leave the monetary base unchanged as the central bank purchases or sells foreign currencies to counter the effect on money supply caused by balanceof-payments deficits or surpluses. Conversely, the non-sterilized interventions will affect the exchange rate through the central bank purchases or sales of domestic securities. As such, the change of monetary base and subsequently improve the interest rates, real demand for goods and assets, and market expectations.

In the literature, two main theories explain how central bank interventions (whether sterilised or not) affect the exchange rate (Dominguez and Frankel, 1993). Firstly, the portfolio balance channel states that central bank interventions, which increase the supply of domestic assets relative to foreign assets, would drive down the domestic asset prices and subsequently increase the domestic interest rate. Higher domestic returns prompt investors to substitute foreign assets with domestic assets. Consequently, the local currency appreciates.

Secondly, the signalling channel states that central bank interventions provide new information to economic agents, thereby affecting their expectations about the exchange rate. Fluctuations in expectations create speculation and, therefore, any expected appreciation (depreciation) of the domestic currency will motivate speculators to buy (sell) the currency resulting in real appreciation (depreciation) of the currency itself.

In Indonesia, growing capital outflows in the post-QE period caused the rupiah to depreciate (Indonesia Investments, 2015c). ${ }^{1}$ Hence, the central bank intervened

1 For example, the rupiah suffered its worst depreciation since the Asian Financial Crisis, depreciating by $8.93 \%$ on 3 September 2018 (Iyke, 2019; Juhro and Iyke, 2019). 
and stabilised the rupiah by selling foreign currencies (Indonesia Investments, 2015b). This intervention, in turn, decreased the amount of foreign reserves held by the BI. Lower foreign reserves indicate that the rupiah is losing value relative to the dollar. This information about reserves will affect investor expectations and subsequently prompt investors to sell rupiah holdings and demand foreign currencies. Hence, in the post-QE period, international reserves are expected to precede the currency value (i.e. the values of the spot, forward, and NDF rates), as stated in hypotheses 3 to 5 , respectively.

Our next set of hypotheses relate to the second financial variable, the Indonesian IGS 10-year yield. We hypothesize that:

H6: During the post-QE period, the IGS influences the dollar-rupiah spot rate.

H7: During the post-QE period, the IGS influences the dollar-rupiah forward rate.

H8: During the post-QE period, the IGS influences the dollar-rupiah NDF rate.

Bond yield is an essential determinant of the exchange rate (Clarida and Taylor, 1997; Chen and Tsang, 2013). Changes in the bond yield will affect investors' portfolio as low yield assets will be substituted for higher return assets. Hence, a higher domestic bond yield induces the investor to demand local assets, thereby the domestic currency will appreciate. Therefore, we developed hypotheses 6 to 8 to test the significance of the bond yield in predicting the exchange rate movement in the post-QE period.

\section{DATA AND MODEL}

For the analysis, the paper uses the logarithm changes in the spot, forward, and NDF, which is computed as $R_{i}=\ln \left(\frac{P_{t}}{P_{t-1}}\right)$, where $R_{i}$ and $P_{t}$ denote, respectively, the returns and prices of the exchange rates. Two models are used in this study. The first model uses daily returns of the spot, forward, and non-deliverable forwards from 3 November 2010 to 22 February 2018. The sample period is further divided into two sub-periods: The first sub-period is from 3 November 2010 to 30 September 2014; and the second sub-period is from 30 October 2014 to 22 February 2018, which marks the end of the US QE.

The second model uses monthly data on the spot, forward, NDF, IGS 10- year yield, and international reserves. As shown in Table 1, all the data are obtained from Thomson Reuters Datastream.

As observed in Table 2, all three exchange rates are highly correlated. Figures 2 and 3 show that RNDF is higher than the forward and spot rates before March 2014. Figure 2 further confirms the lead-lag relationship between the forward and spot rates, to the extent that there is co-movement between the two rates. These figures imply some underlying relationship among the three exchange rates, which could be useful to policymakers in understanding the intricacy of dollarrupiah movement. 
Table 1.

\section{List of Variables}

The first model employs daily data, while the second model employs monthly data. The sample period for the first model is $3 / 11 / 2010$ to $30 / 9 / 2014$ and from 30/10/2014 to 22/2/2018. The sample period for the second model is $11 / 2010$ to $9 / 2014$ and from 10/2014 to 2/2018. BI denotes Bank Indonesia.

\begin{tabular}{|c|c|c|c|}
\hline Variables & Description & $\begin{array}{c}\text { Unit of } \\
\text { measurement }\end{array}$ & Source \\
\hline \multicolumn{4}{|c|}{ First model } \\
\hline$R S P$ & Percentage returns on USD to IDR spot rate & Daily returns & Reuters \\
\hline RFWD & Percentage returns on 1-month forward USD to IDR rate & Daily returns & Reuters \\
\hline RNDF & Percentage returns on 1-month NDF USD to IDR rate & Daily returns & Reuters \\
\hline \multicolumn{4}{|c|}{ Second model } \\
\hline RSP & Percentage returns on USD to IDR spot rate & Monthly returns & Reuters \\
\hline RFWD & Percentage returns on 1-month forward USD to IDR rate & Monthly returns & Reuters \\
\hline RNDF & Percentage returns on 1-month NDF USD to IDR rate & Monthly returns & Reuters \\
\hline IGS & Indonesia government securities 10 - year yield & Interest rate & Reuters \\
\hline Reserve & International reserve & Million USD & BI \\
\hline
\end{tabular}

Table 2.

\section{Correlation Matrix of All Variables}

This table shows the correlation between all the variables. The table reports the associated correlation matrix.

\begin{tabular}{lccccc}
\hline & RNDF & RSP & RFWD & IGS & RESERVE \\
\hline RNDF & 1.00 & & & & \\
RSP & 0.88 & 1.00 & & & \\
RFWD & 0.89 & 0.99 & 1.00 & & \\
IGS & 0.09 & 0.12 & 0.12 & 1.00 & \\
RESERVE & -0.13 & -0.17 & -0.17 & -0.45 & 1.00 \\
\hline
\end{tabular}

Figure 2.

The plot of Returns of Spot, Forward and NDF of USD-IDR Exchange Rate

This figure shows the plot of returns between the three types of exchange rate.

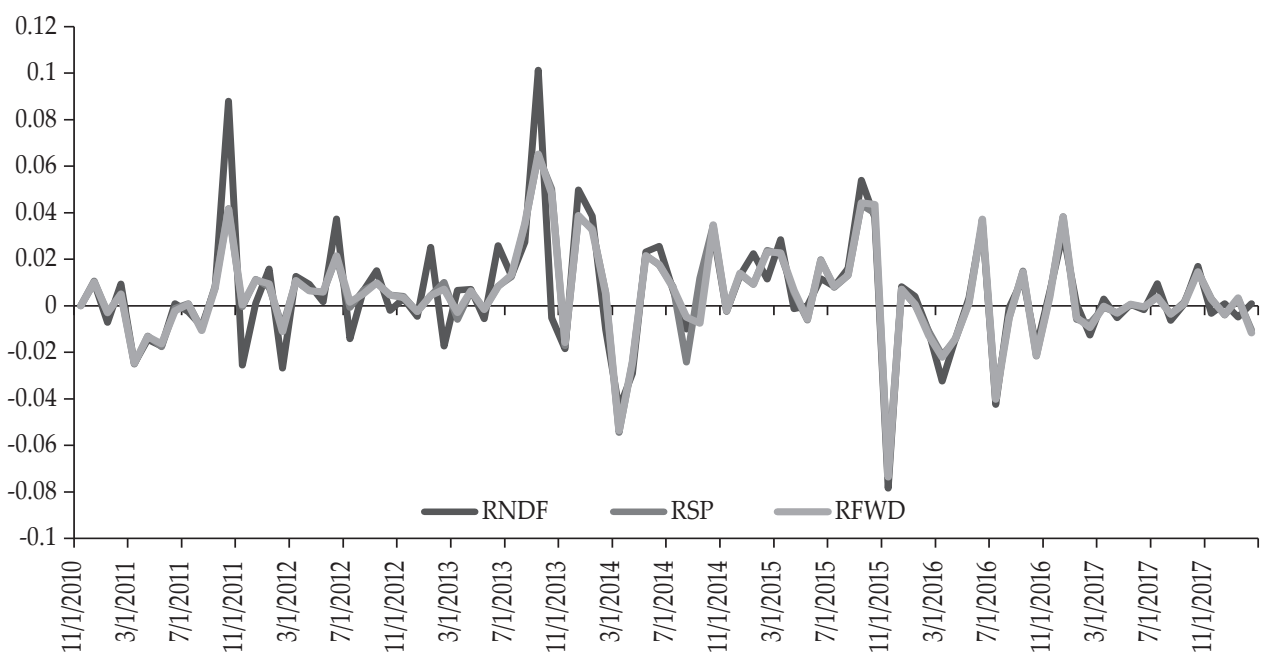


Figure 3.

The Plot of Returns of Forward and NDF of USD-IDR Exchange Rate

This figure shows the plot of returns of forward and the NDF rate.

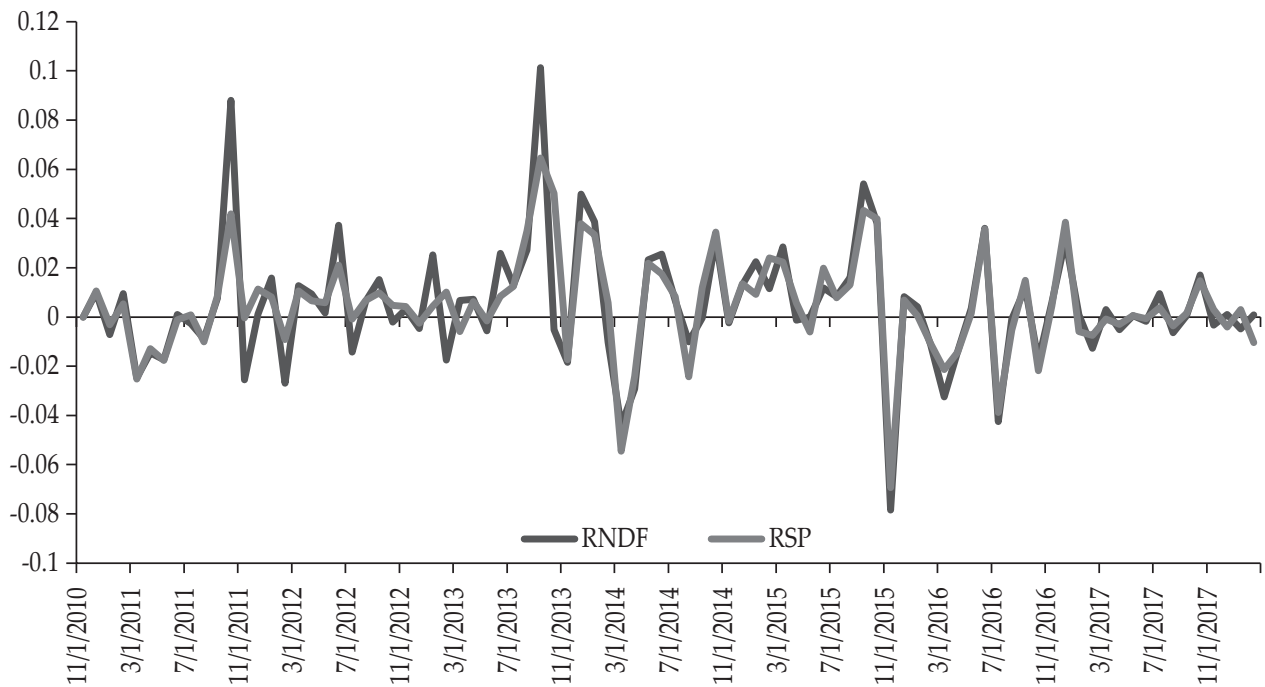

Table 3 presents the descriptive statistics for all the series. In the first model, it can be observed that changes in the spot and forward rates became more volatile (as indicated by a higher standard deviation) in the post-QE relative to the QE period. In contrast, the changes in NDF exhibit a lower standard deviation in the QE exit period.

For the second model, we observe a similar trend for the spot, forward, and reserve rates. They are more volatile during post-QE exit than the QE period. Moreover, both NDF and IGS became less volatile after the end of QE.

Table 3.

\section{Descriptive Statistics}

The first model uses daily data, and the second model uses monthly data. The sample period for the first and second model is sub-divided into QE and Post-QE periods. RSP denotes percentage returns on the USD to IDR spot rate. RFWD denotes percentage returns on the 1-month forward USD to IDR rate. RNDF denotes percentage returns on the 1-month NDF USD to IDR rate. IGS denotes Indonesia government securities 10- year yield. Reserve denotes International reserve.

\begin{tabular}{|c|c|c|c|c|c|c|}
\hline Variable & Mean & Std Dev & Skewness & Kurtosis & J-B statistic & Obs \\
\hline \multicolumn{7}{|c|}{ First model } \\
\hline \multicolumn{7}{|c|}{ QE period (3/11/2010 - 30/9/2014) } \\
\hline$R S P$ & 0.0003 & 0.0035 & 0.4795 & 12.5776 & $3937.651(0.000)$ & 1020 \\
\hline RFWD & 0.0003 & 0.0036 & 0.4224 & 11.7450 & $3280.546(0.000)$ & 1020 \\
\hline RNDF & 0.0003 & 0.0060 & 0.2512 & 9.3111 & $1703.390(0.000)$ & 1020 \\
\hline \multicolumn{7}{|c|}{ Post-QE period (30/10/2014 - 22/2/2018) } \\
\hline$R S P$ & 0.0001 & 0.0037 & -1.4067 & 17.2037 & $7656.261(0.000)$ & 866 \\
\hline RFWD & 0.0001 & 0.0038 & -1.3669 & 17.1926 & $7537.964(0.000)$ & 866 \\
\hline RNDF & 0.0001 & 0.0055 & -0.2691 & 9.3255 & $1454.207(0.000)$ & 866 \\
\hline
\end{tabular}


Table 3.

Descriptive Statistics (Continued)

\begin{tabular}{|c|c|c|c|c|c|c|}
\hline Variable & Mean & Std Dev & Skewness & Kurtosis & J-B statistic & Obs \\
\hline \multicolumn{7}{|c|}{ Second model } \\
\hline \multicolumn{7}{|c|}{ QE period (11/2010 - 9/2014) } \\
\hline$R S P$ & 0.0058 & 0.0199 & 0.2767 & 5.1138 & $9.3499(0.009)$ & 47 \\
\hline RFWD & 0.0058 & 0.0198 & 0.3157 & 5.0237 & $8.8010(0.0123)$ & 47 \\
\hline RNDF & 0.0059 & 0.0267 & 1.4599 & 6.3963 & $39.2858(0.000)$ & 47 \\
\hline IGS & 7.0581 & 1.1975 & -0.0510 & 1.5673 & $4.0400(0.1327)$ & 47 \\
\hline Reserve & $107,038.50$ & $7,791.62$ & -0.0699 & 2.5553 & $0.4256(0.8083)$ & 47 \\
\hline \multicolumn{7}{|c|}{ Post-OE period $(10 / 2014-2 / 2018)$} \\
\hline$R S P$ & 0.0037 & 0.0209 & -0.7709 & 5.5170 & $14.5206(0.007)$ & 41 \\
\hline RFWD & 0.0036 & 0.0217 & -0.8325 & 5.8265 & $17.9354(0.000)$ & 41 \\
\hline RNDF & 0.0033 & 0.0226 & -0.9750 & 6.3159 & $24.6635(0.000)$ & 41 \\
\hline IGS & 7.5841 & 0.7914 & 0.4120 & 2.5554 & $1.4612(0.482)$ & 41 \\
\hline Reserve & $114,751.80$ & $9,134.42$ & 0.3058 & 1.9816 & $2.4109(0.300)$ & 41 \\
\hline
\end{tabular}

\section{EMPIRICAL ANALYSIS}

A. Unit Root Test

Since there exist two structural breaks in level and slope at an unknown time, this study employs a test proposed by Narayan and Popp (2010). This is an augmented Dickey-Fuller-type test for unit roots, which accounts for two structural breaks under two different specifications: two breaks in the level of a trending data series; and two breaks in the level and slope of a trending series. The breaks, whose time of occurrence is assumed to be unknown are modelled as outliers.

Panel A of Table 4, which shows results based on the first model, indicates that all the series are stationary at the conventional significance levels. Panel B of Table 4 (i.e. results based on the second model), suggests that RSP, RFWD, and RNDF are stationary, while IGS and Reserve are not stationary. These results are consistent with the standard ADF and KPSS test results shown in Table 5 and 6. For the first model, the ADF and KPSS test results show that all series are stationary at level for both the pre- and post-QE period. For the second model (in Table 4), RSP, RWD, and RNDF are stationary in level form in the pre- and post-QE periods. Next, the IGS and Reserve variables are transformed into natural logarithm form. Both series become stationary after taking the first difference in both the pre- and post-QE periods. 
Table 4.

Narayan and Popp (2010) Unit Root Test with Two Structural Breaks

Panel A shows the results of the model for the unit root test with two structural breaks. All series are stationary irrespective whether it contains one or two structural breaks. Panel B shows the results of the second model. All variables are stationary except IGS and Reserve. Model-1 assumes two breaks in level and Model-2 assumes two breaks in the level as well as the slope. The asterisks *** and ${ }^{* * *}$ denote $10 \%, 5 \%$ and $1 \%$ level of significance, respectively.

\begin{tabular}{|c|c|c|c|c|c|c|}
\hline \multicolumn{7}{|c|}{ Panel A: First model (Daily data) } \\
\hline \multirow{2}{*}{ Variables } & \multicolumn{3}{|c|}{ Model 1 (M1) } & \multicolumn{3}{|c|}{ Model 2 (M2) } \\
\hline & $T$-statistics & TB1 & TB2 & $T$-statistics & TB1 & TB2 \\
\hline$R S P$ & $-22.30^{* * *}$ & $22 / 11 / 2012$ & $19 / 4 / 2013$ & $-22.42^{* * *}$ & $14 / 9 / 2012$ & $19 / 4 / 2013$ \\
\hline RFWD & $-45.91^{* * *}$ & $21 / 11 / 2012$ & $19 / 4 / 2013$ & $-45.89^{* * *}$ & $21 / 11 / 2012$ & $19 / 4 / 2013$ \\
\hline RNDF & $-20.21^{* * *}$ & $19 / 4 / 2013$ & $12 / 4 / 2014$ & $-20.16^{* * *}$ & $19 / 4 / 2013$ & $12 / 4 / 2014$ \\
\hline \multicolumn{7}{|c|}{ Panel B: Second model (Monthly data) } \\
\hline \multirow{2}{*}{ Variables } & \multicolumn{3}{|c|}{ Model 1 (M1) } & \multicolumn{3}{|c|}{ Model 2 (M2) } \\
\hline & T- statistics & TB1 & TB2 & T- statistics & TB1 & TB2 \\
\hline$R S P$ & $-9.63^{* * *}$ & $11 / 2014$ & $11 / 2015$ & $-10.13^{* * *}$ & $6 / 2012$ & $11 / 2015$ \\
\hline RFWD & $-9.11^{* * *}$ & $11 / 2014$ & $11 / 2015$ & $-9.43^{* * *}$ & $6 / 2012$ & $11 / 2014$ \\
\hline$R N D F$ & $-11.29^{* * *}$ & $11 / 2014$ & $12 / 2015$ & $-11.05^{* * *}$ & $4 / 2012$ & $11 / 2014$ \\
\hline IGS & -4.20 & $4 / 2012$ & $10 / 2015$ & -4.49 & $11 / 2012$ & $10 / 2015$ \\
\hline Reserve & -2.85 & 6/2014 & $11 / 2014$ & -2.80 & 6/2014 & $11 / 2014$ \\
\hline
\end{tabular}

Table 5.

\section{Unit Root and Stationary Test for the First Model}

The table shows the unit root test results for first model, which uses daily data. The QE period is from 3/11/2010 to $30 / 9 / 2014$. The post-QE period is from 30/10/2014 to 22/2/2018. RSP denotes percentage returns on the USD to IDR spot rate. RFWD denotes percentage returns on the 1-month forward USD to IDR rate. RNDF denotes percentage returns on the 1-month NDF USD to IDR rate. IGS denotes Indonesia Government Securities 10- year yield. Reserve denotes International reserve. The asterisks ${ }^{*}, * *$ and ${ }^{* * *}$ denote significance at the $10 \%, 5 \%$ and $1 \%$ levels, respectively. Figures in the parentheses are the optimal lag length chosen. KPSS test is based on Kwiatkowski et al., (1992).

\begin{tabular}{|c|c|c|c|c|}
\hline \multirow{2}{*}{ Variable } & \multicolumn{2}{|c|}{ ADF test } & \multicolumn{2}{|c|}{ KPSS test } \\
\hline & Level & First difference & Level & First difference \\
\hline \multicolumn{5}{|l|}{ QE period } \\
\hline$\hat{R S P}$ & $-11.93(4)^{* *}$ & & $0.30(13)$ & \\
\hline RFWD & $-30.69(0)^{* *}$ & & $0.31(12)$ & \\
\hline RNDF & $-32.63(0)^{* *}$ & & $0.14(9)$ & \\
\hline \multicolumn{5}{|c|}{ Post-QE period } \\
\hline$R S P$ & $-26.36(0)^{* *}$ & & $0.17(4)$ & \\
\hline RFWD & $-26.39(0)^{* *}$ & & $0.18(4)$ & \\
\hline RNDF & $-22.52(1)^{* *}$ & & $0.15(13)$ & \\
\hline
\end{tabular}


Table 6.

\section{Unit Root and Stationary Test for the Second Model}

The table shows the unit root test for the second model, which uses monthly data. The QE period is from November 2010 to September 2014. The Post-QE period is from October 2014 to February 2018. RSP denotes percentage returns on the USD to IDR spot rate. RFWD denotes percentage returns on the 1-month forward USD to IDR rate. RNDF denotes percentage returns on the 1-month NDF USD to IDR rate. IGS denotes Indonesia Government Securities 10year yield. Reserve denotes International reserve. The asterisks *** and ${ }^{* * *}$ denote significance at the $10 \%, 5 \%$ and $1 \%$ levels, respectively. Figures in the parentheses are the optimal lag length chosen. $L n$ denotes the series is transformed into natural logarithm form. KPSS test is based on Kwiatkowski et al., (1992).

\begin{tabular}{lcccc}
\hline \multirow{2}{*}{ Variables/Period } & \multicolumn{2}{c}{ ADF Test } & \multicolumn{2}{c}{ KPSS test } \\
\cline { 2 - 5 } & Level & $\begin{array}{c}\text { First } \\
\text { difference }\end{array}$ & Level & $\begin{array}{c}\text { First } \\
\text { difference }\end{array}$ \\
\hline QE period & & & & \\
\hline RSP & $-4.59(0)^{* *}$ & & $0.19(1)$ & \\
RFWD & $-4.57(0)^{* *}$ & & $0.19(1)$ & \\
RNDF & $-6.57(0)^{* *}$ & & $0.13(1)$ & \\
LnIGS & $-1.23(0)$ & $-6.16(0)^{* * *}$ & $0.60(1)^{* *}$ & $0.17(1)$ \\
LnReserve & $-2.11(0)$ & $-4.67(0)^{* * *}$ & $0.83(0)^{* *}$ & $0.17(3)$ \\
\hline Post-QE period & & & & \\
\hline RSP & $-6.91(0)^{* *}$ & & $0.29(1)$ & \\
RFWD & $-6.96(0)^{* *}$ & & $0.29(1)$ & \\
RNDF & $-6.62(0)^{* *}$ & & $0.24(1)$ & \\
LnIGS & $-1.41(0)$ & $-6.27(0)^{* *}$ & $0.49(5)^{* *}$ & $0.06(3)$ \\
LnReserve & $-0.48(0)$ & $-7.01(0)^{* * *}$ & $0.56(5)^{* *}$ & $0.20(0)$ \\
\hline
\end{tabular}

\section{B. Granger's Causality}

We employ the Engle and Granger's (1987) intuition to construct a Granger causality test for both models. Based on the Schwarz information criterion, the optimal lag length for the pre- and post-QE models are five and two, respectively. In Panel A of Table 7, we found that during the US QE period, bidirectional causality exists between the NDF and spot rates, and the spot and forward rates. Moreover, there is a unidirectional causality from NDF to forward rate.

In Panel B of Table 7, we found that there is a strong unidirectional causality running from $N D F$ to spot rate and from the NDF to forward rate for the postQE exit period. Hence, we failed to reject hypotheses 1 and 2 at the $1 \%$ level of significance, meaning that the NDF precedes the movement of the rupiah spot and forward rates.

The end of the US QE triggered capital outflows from Indonesia, and given the convertibility restrictions on the IDR, investors engaged in the purchase of NDF to hedge against the currency depreciation (Kong and Shao, 2010; Wang et al., 2014). Hence, there is a robust one-way causality running from NDF to the spot rate, and from the NDF to the forward rate. This finding is supported by results shown in Table 8. 
Table 7.

\section{Granger Causality Between Exchange Rates for the First Model}

Panel A shows the results for the first model (daily data) from 3 November 2010 to 30 September 2014. Panel B shows the results from 30 October 2014 to 22 February 2018. The asterisks **** and *** denote significance at the $10 \%, 5 \%$ and $1 \%$ levels, respectively. All estimates are asymptotic Granger Chi-squared statistics. Values in parentheses are $p$-values.

\begin{tabular}{lccc}
\hline \multicolumn{3}{l}{ Panel A: Granger's causality results for QE Period } \\
\hline \multirow{2}{*}{ Dependent Variables } & \multicolumn{3}{l}{ Independent variables } \\
\cline { 2 - 4 } & & $R S P D$ & RNDF \\
\hline \multirow{2}{*}{ RSP } & & 10.369 & 90.419 \\
\multirow{2}{*}{ RFWD } & 32.629 & $(0.065)^{*}$ & $(0.000)^{* * *}$ \\
\multirow{2}{*}{ RNDF } & $(0.000)^{* * *}$ & & 87.529 \\
& 10.874 & & $(0.000)^{* * *}$ \\
\hline
\end{tabular}

Panel B: Granger's causality results for Post-QE Period

\begin{tabular}{lccc}
\hline \multirow{2}{*}{ Dependent Variables } & \multicolumn{3}{c}{ Independent variables } \\
\cline { 2 - 4 } & $R S P$ & RFWD & RNDF \\
\hline \multirow{2}{*}{ RSP } & & 9.766 & 94.984 \\
& & $(0.008)^{* * *}$ & $(0.000)^{* * *}$ \\
\multirow{2}{*}{ RFWD } & 7.288 & & 95.144 \\
\multirow{2}{*}{ RNDF } & $(0.026)^{* *}$ & & $(0.000)^{* * *}$ \\
& 2.619 & 2.527 & \\
\hline
\end{tabular}

Despite having a rebound in capital flows in 2016, Indonesia experienced a negative portfolio equity inflow in 2015, 2017, and 2018. This is consistent with the argument that Indonesia experienced capital outflows in the post-QE period. Moreover, the capital outflows in 2017 and 2018 are substantial compared to the pre-QE period (2010-2014).

Table 8.

Portfolio Equity, Net Inflow (Million USD)

This table shows the net inflow of portfolio equity to Indonesia. Source: World Bank, World Development Indicators. (2019). Portfolio equity, net inflows (BoP, current US\$). Retrieved from https://data.worldbank.org/indicator/BX.PEF. TOTL.CD.WD

\begin{tabular}{lc}
\hline Year & Portfolio equity, net inflow (Million USD) \\
\hline 2010 & 2131.563 \\
2011 & -326.105 \\
2012 & 1697.642 \\
2013 & -1855.99 \\
2014 & 3259.252 \\
2015 & -1546.73 \\
2016 & 1318.639 \\
2017 & -2537.67 \\
2018 & -3668.29 \\
\hline
\end{tabular}


Moreover, the results show that the forward exchange rate lost its predictive power over the NDF rate in the post-QE period. This may be attributed to market participants' belief that prices in the offshore market rate are likely to reflect better global market conditions than the onshore market rate (Ishii et al., 2001; and Maziad and Kang, 2012). Given the convertibility restrictions of the IDR, investors will substitute forward contracts with the NDF contract (Cadarajat and Lubis, 2012).

As a result, we found the dollar-rupiah NDF exchange rate to dictate the movement of the spot and forward rates in the post-QE period. This indicates that the depreciation (appreciation) of the IDR in the NDF market would result in the depreciation (appreciation) of the rupiah spot and forward exchange rates.

Panels A and B of Table 9 show the results for the second model. The optimal lag length used in this case is five and two for the pre- and post-QE period, respectively. We find that during the QE period, IGS played a dominant role in transmitting information to the spot, forward, and NDF rates. However, the causality from IGS to the spot, forward, and NDF rates are insignificant in the post-QE period. Hence, we reject hypotheses 6 to 8 .

Table 9.

\section{Granger Causality Between Exchange Rates for the Second Model}

Panel A shows the results for the second model (monthly data) from November 2010 to September 2014. Panel B shows the results from October 2014 to February 2018. The asterisks *,** and *** denote significance at the 10\%, 5\% and $1 \%$ levels, respectively. All estimates are asymptotic Granger Chi-squared statistics. Values in parentheses are $p$-values. $L n$ denotes the series is transformed into a natural logarithm.

\begin{tabular}{|c|c|c|c|c|c|}
\hline \multicolumn{6}{|c|}{ Panel A: Granger's causality results for QE period } \\
\hline \multirow{2}{*}{ Dependent Variables } & \multicolumn{5}{|c|}{ Independent variables } \\
\hline & RSP & RFWD & RNDF & $\Delta \operatorname{LnIGS}$ & $\Delta$ LnReserve \\
\hline RSP & & $\begin{array}{c}15.541 \\
(0.008)^{* * *}\end{array}$ & $\begin{array}{c}25.051 \\
(0.000)^{* * *}\end{array}$ & $\begin{array}{c}13.649 \\
(0.018)^{* *}\end{array}$ & $\begin{array}{c}7.747 \\
(0.171)\end{array}$ \\
\hline RFWD & $\begin{array}{l}16.282 \\
(0.006)^{* * *}\end{array}$ & & $\begin{array}{l}24.938 \\
(0.000)^{* * *}\end{array}$ & $\begin{array}{c}14.487 \\
(0.013)^{* *}\end{array}$ & $\begin{array}{l}7.497 \\
(0.186)\end{array}$ \\
\hline RNDF & $\begin{array}{c}12.314 \\
(0.031)^{* *}\end{array}$ & $\begin{array}{c}11.624 \\
(0.040)^{* *}\end{array}$ & & $\begin{array}{c}12.885 \\
(0.025)^{* *}\end{array}$ & $\begin{array}{l}6.786 \\
(0.237)\end{array}$ \\
\hline$\triangle L n I G S$ & $\begin{array}{l}5.056 \\
(0.409)\end{array}$ & $\begin{array}{l}5.109 \\
(0.403)\end{array}$ & $\begin{array}{c}9.289 \\
(0.098)^{*}\end{array}$ & & $\begin{array}{c}12.139 \\
(0.033)^{* *}\end{array}$ \\
\hline$\Delta$ LnReserve & $\begin{array}{c}3.733 \\
(0.588) \\
\end{array}$ & $\begin{array}{c}3.803 \\
(0.578) \\
\end{array}$ & $\begin{array}{r}2.276 \\
(0.809) \\
\end{array}$ & $\begin{array}{c}1.641 \\
(0.896)\end{array}$ & \\
\hline \multicolumn{6}{|c|}{ Panel B: Granger's causality results for Post-QE period } \\
\hline \multirow{2}{*}{ Dependent Variables } & \multicolumn{5}{|c|}{ Independent variables } \\
\hline & RSP & RFWD & RNDF & $\Delta L n I G S$ & $\Delta$ LnReserve \\
\hline RSP & & $\begin{array}{c}10.946 \\
(0.004)^{* * *}\end{array}$ & $\begin{array}{c}8.910 \\
(0.012)^{* *}\end{array}$ & $\begin{array}{c}2.163 \\
(0.339)\end{array}$ & $\begin{array}{c}6.843 \\
(0.033)^{* *}\end{array}$ \\
\hline RFWD & $\begin{array}{c}9.724 \\
(0.008)^{* * *}\end{array}$ & & $\begin{array}{c}8.649 \\
(0.013)^{* *}\end{array}$ & $\begin{array}{c}2.359 \\
(0.307)\end{array}$ & $\begin{array}{c}6.561 \\
(0.038)^{* *}\end{array}$ \\
\hline RNDF & $\begin{array}{c}7.025 \\
(0.029)^{* *}\end{array}$ & $\begin{array}{c}7.483 \\
(0.024)^{* *}\end{array}$ & & $\begin{array}{c}2.301 \\
(0.317)\end{array}$ & $\begin{array}{c}6.138 \\
(0.047)^{* *}\end{array}$ \\
\hline$\triangle L n I G S$ & $\begin{array}{c}0.955 \\
(0.620)\end{array}$ & $\begin{array}{l}1.642 \\
(0.440)\end{array}$ & $\begin{array}{c}4.486 \\
(0.088)^{*}\end{array}$ & & $\begin{array}{c}4.168 \\
(0.125)\end{array}$ \\
\hline$\Delta$ LnReserve & $\begin{array}{c}1.552 \\
(0.460) \\
\end{array}$ & $\begin{array}{c}2.353 \\
(0.308)\end{array}$ & $\begin{array}{c}2.768 \\
(0.251)\end{array}$ & $\begin{array}{c}3.966 \\
(0.138) \\
\end{array}$ & \\
\hline
\end{tabular}


Therefore, changes in the bond yield were insufficient to reverse selling pressures on the IDR and to restore investor confidence, consistent with Suhartono and Carson (2018). Conversely, we found that there is a unidirectional causality from international reserves to the dollar-rupiah spot exchange rate in the post-QE period. Similarly, reserves Granger cause forward and NDF rates. These results support hypotheses 3, 4 and 5 .

The results suggest that international reserves are imperative in explaining movements in the NDF, spot and forward rates in the post-QE period. Changes in reserves would affect investor expectations and, thereby, influence the currency value (Dominguez and Frankel, 1993). The size of foreign reserves held by the central bank indicates the ability of the bank to provide emergency foreign currency funding to stabilise the currency value in the event of financial stress (Fatum and Yetman, 2017). Therefore, lower international reserves imply a smaller capacity of the central bank in stabilising the IDR value during episodes of capital outflows. Subsequently, lower reserves holding will prompt investors to sell their IDR holdings. Thus, foreign reserves played an essential role in predicting the movement of the spot, forward and NDF exchange rates in the post- QE period.

\section{Robustness Test}

Sims et al. (1990) show that inference based on level VAR is valid since the Wald test used in Granger causality tests has a limiting chi-square distribution if the time series variables are cointegrated. However, this approach has a limitation as it depends on pre-testing for a cointegrating relationship. It is also inapplicable to mixed orders of integration processes. An improved method proposed by Toda and Yamamoto (1995) is complementary to the Sims et al. (1990) technique because it allows for causal inference based on augmented level VAR with integrated and cointegrated processes. This method is useful because it bypasses the need for potentially biased pre-test for unit roots and cointegration common to other methods (see Takumah and Iyke, 2017).

The Toda and Yamamoto (1995) procedure used a modified Wald (MWALD) test to examine restrictions on the parameters of a $\operatorname{VAR}(k)$ model. This test has an asymptotic chi-squared distribution with $k$ degrees of freedom in the limit when a $\operatorname{VAR}[k+\mathrm{d}(\max )]$ is estimated, where $\mathrm{d}(\max )$ is the maximum order of integration for the series in the system. Two steps are involved in implementing the procedure. The first step includes the determination of the lag length $(k)$ and the maximum order of integration (d) of the variables in the system.

Information criteria, such as the Akaike Information Criterion (AIC) and the Hannan-Quinn (HQ) Information Criterion, are used to determine the appropriate lag structure of the VAR model. Given the VAR $(k)$ selected, and that the order of integration $\mathrm{d}(\max )$ is determined, a level VAR can then be estimated with a total of $p=[k+\mathrm{d}(\max )]$ lags. The second step is to apply the standard Wald tests to the first $k$ VAR coefficient matrix (but not all lagged coefficients) to conduct inference on Granger causality.

Since all the variables are in levels, no short-run causal flows exist. Instead, the results provide information about the long-run causal flows among the series. Interestingly, the Toda-Yamamoto test results in Table 10 are consistent with 
the traditional VAR Granger causality test results in Tables 8 and 9. The results indicate that IGS has a vital role during the QE period, while a feedback causality exists between reserves and the spot, forward and NDF dollar-rupiah exchange rates in the post-QE period.

Table 10.

\section{Augmented VAR Results for the Second Model}

Panel A shows the results for the second model (monthly data) during the QE period from November 2010 to September 2014. In contrast, Panel B shows the results during Post-QE period from October 2014 to February 2018. The asterisks ${ }^{*}, * *$ and ${ }^{* * *}$ denote significance at the $10 \%, 5 \%$ and $1 \%$ levels, respectively. The $[\mathrm{k}+\mathrm{d}(\mathrm{max})]$ th order-level VAR was estimated with $\mathrm{d}(\max )=1$, since the order of integration is 1 . Lag length selection of $i=5$ and 2 for Panel A and B, respectively. All estimates are asymptotic Granger Chi-squared statistics. Values in parentheses are $p$-values.

\begin{tabular}{|c|c|c|c|c|c|}
\hline \multicolumn{6}{|c|}{ Panel A: Toda-Yamamoto Augmented VAR for QE Period } \\
\hline \multirow{2}{*}{ Dependent Variables } & \multicolumn{5}{|c|}{ Independent variables } \\
\hline & RSP & RFWD & RNDF & LnIGS & LnReserve \\
\hline RSP & & $\begin{array}{l}14.787 \\
(0.011)^{* *}\end{array}$ & $\begin{array}{c}19.403 \\
(0.002)^{* * *}\end{array}$ & $\begin{array}{c}11.625 \\
(0.040)^{* *}\end{array}$ & $\begin{array}{l}8.239 \\
(0.144)\end{array}$ \\
\hline RFWD & $\begin{array}{c}14.901 \\
(0.011)^{* *}\end{array}$ & & $\begin{array}{c}19.141 \\
(0.002)^{* * *}\end{array}$ & $\begin{array}{l}12.081 \\
(0.034)^{* *}\end{array}$ & $\begin{array}{l}7.894 \\
(0.162)\end{array}$ \\
\hline RNDF & $\begin{array}{c}13.245 \\
(0.021)^{* *}\end{array}$ & $\begin{array}{l}12.868 \\
(0.025)^{* *}\end{array}$ & & $\begin{array}{c}9.458 \\
(0.092)^{*}\end{array}$ & $\begin{array}{c}8.215 \\
(0.145)\end{array}$ \\
\hline LnIGS & $\begin{array}{l}2.831 \\
(0.726)\end{array}$ & $\begin{array}{c}2.680 \\
(0.749)\end{array}$ & $\begin{array}{c}5.525 \\
(0.355)\end{array}$ & & $\begin{array}{c}9.239 \\
(0.100)\end{array}$ \\
\hline LnReserve & $\begin{array}{l}1.280 \\
(0.937)\end{array}$ & $\begin{array}{c}1.239 \\
(0.941)\end{array}$ & $\begin{array}{c}0.642 \\
(0.986)\end{array}$ & $\begin{array}{l}1.499 \\
(0.913)\end{array}$ & \\
\hline \multicolumn{6}{|c|}{ Panel B: Toda-Yamamoto Augmented VAR for Post-QE Period } \\
\hline \multirow{2}{*}{ Dependent Variables } & \multicolumn{5}{|c|}{ Independent variables } \\
\hline & $R S P$ & RFWD & RNDF & LnIGS & LnReserve \\
\hline$R S P$ & & $\begin{array}{c}13.649 \\
(0.001)^{* * *}\end{array}$ & $\begin{array}{c}11.614 \\
(0.003)^{* * *}\end{array}$ & $\begin{array}{l}0.267 \\
(0.875)\end{array}$ & $\begin{array}{l}9.040 \\
(0.011)^{* *}\end{array}$ \\
\hline RFWD & $\begin{array}{c}12.228 \\
(0.002)^{* * *}\end{array}$ & & $\begin{array}{c}11.403 \\
(0.003)^{* * *}\end{array}$ & $\begin{array}{l}0.282 \\
(0.868)\end{array}$ & $\begin{array}{c}8.596 \\
(0.014)^{* *}\end{array}$ \\
\hline RNDF & $\begin{array}{c}9.681 \\
(0.008)^{* * *}\end{array}$ & $\begin{array}{c}10.323 \\
(0.006)^{* * *}\end{array}$ & & $\begin{array}{l}0.412 \\
(0.814)\end{array}$ & $\begin{array}{c}7.472 \\
(0.024)^{* *}\end{array}$ \\
\hline LnIGS & $\begin{array}{c}0.505 \\
(0.777)\end{array}$ & $\begin{array}{c}0.876 \\
(0.645)\end{array}$ & $\begin{array}{c}3.052 \\
(0.217)\end{array}$ & & $\begin{array}{c}2.038 \\
(0.361)\end{array}$ \\
\hline LnReserve & $\begin{array}{l}1.661 \\
(0.436)\end{array}$ & $\begin{array}{c}2.543 \\
(0.280)\end{array}$ & $\begin{array}{c}2.864 \\
(0.239)\end{array}$ & $\begin{array}{c}3.281 \\
(0.194)\end{array}$ & \\
\hline
\end{tabular}

D. Further Analysis

From the first VAR model, we generated generalised impulse response functions. Figure 4 shows the impulse response functions for the first model, which used spot, forward and NDF rates. Since the exchange rate is defined as the IDR per dollar (USD/IDR), an increase in the exchange rate implies a depreciation of the IDR and vice versa. 
Figure 4.

\section{Impulse Response Function}

Figures $4 \mathrm{a}$ and $4 \mathrm{~b}$ show the impulse response function between spot and NDF during QE and Post-QE. Figures 4c and $4 \mathrm{~d}$ show the impulse response function between forward and NDF during QE and Post-QE. The US QE sample period is from 3/11/2010 to 30/9/2014. The sample period for Post- QE is from 30/10/2014 to 22/2/2018. RSP denotes percentage returns on USD to IDR spot rate, RFWD indicates percentage returns on 1-month forward USD to IDR rate, and the RNDF indicates percentage returns on 1-month NDF USD to IDR rate.

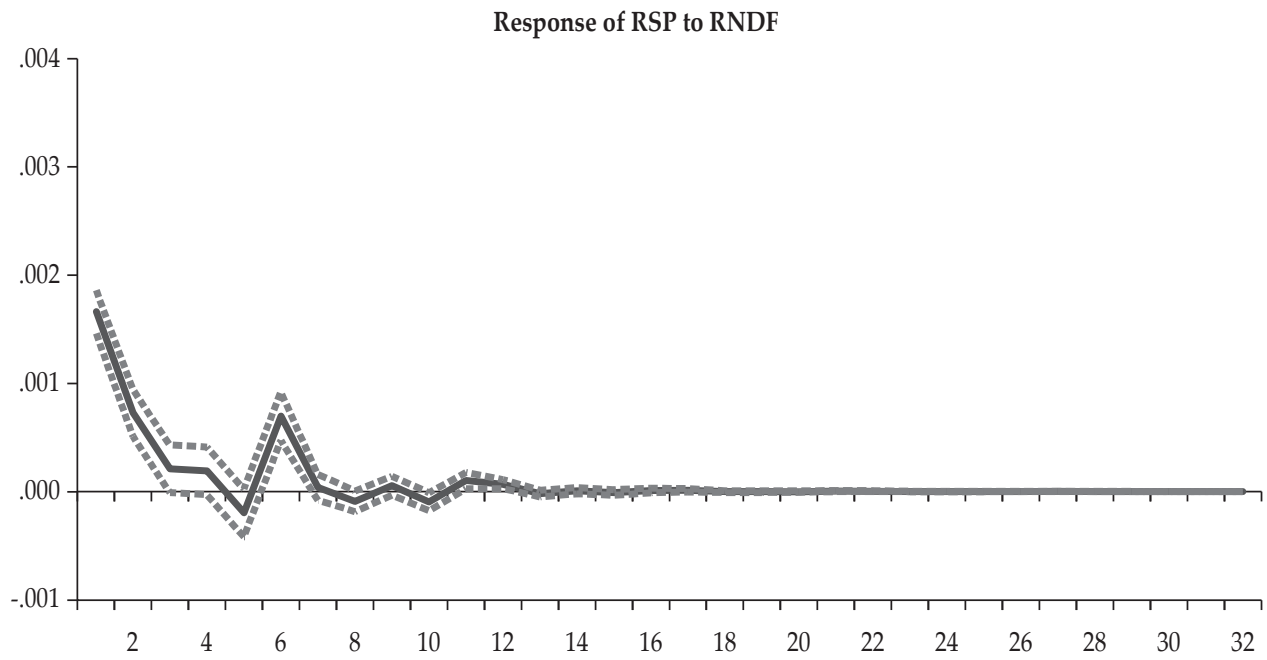

4a: Response of RSP to RNDF (QE)

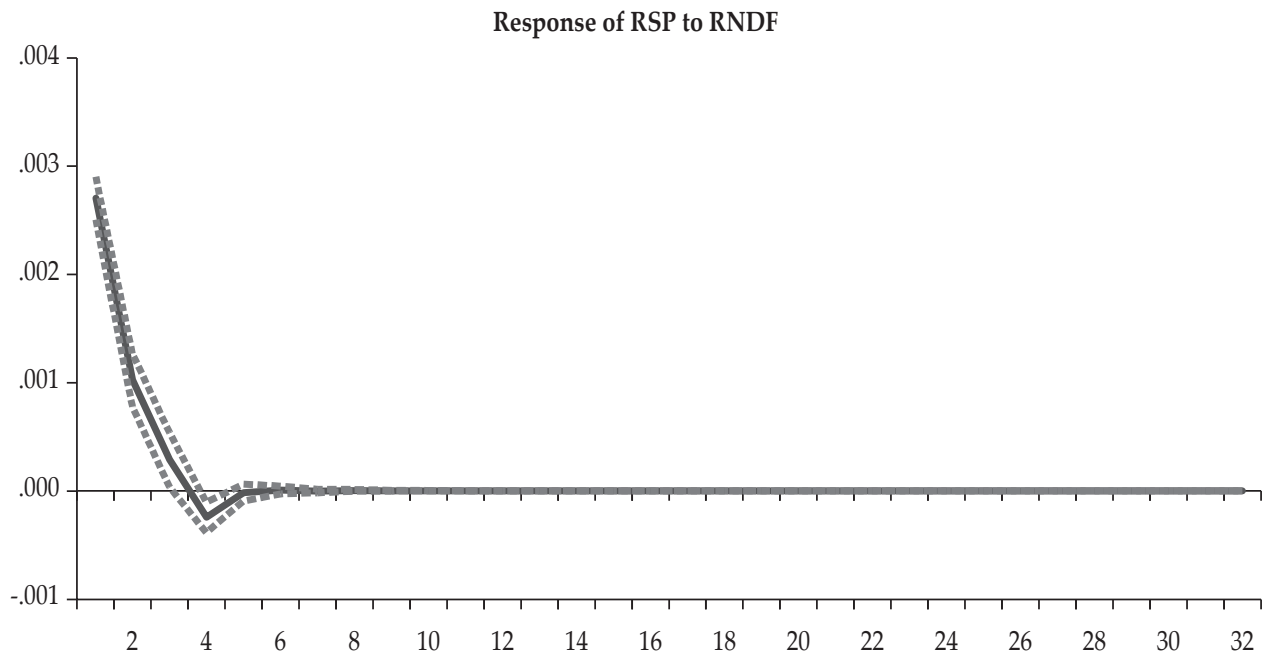

4b: Response of RSP to RNDF (Post- QE) 
Figure 4.

Impulse Response Function (Continued)
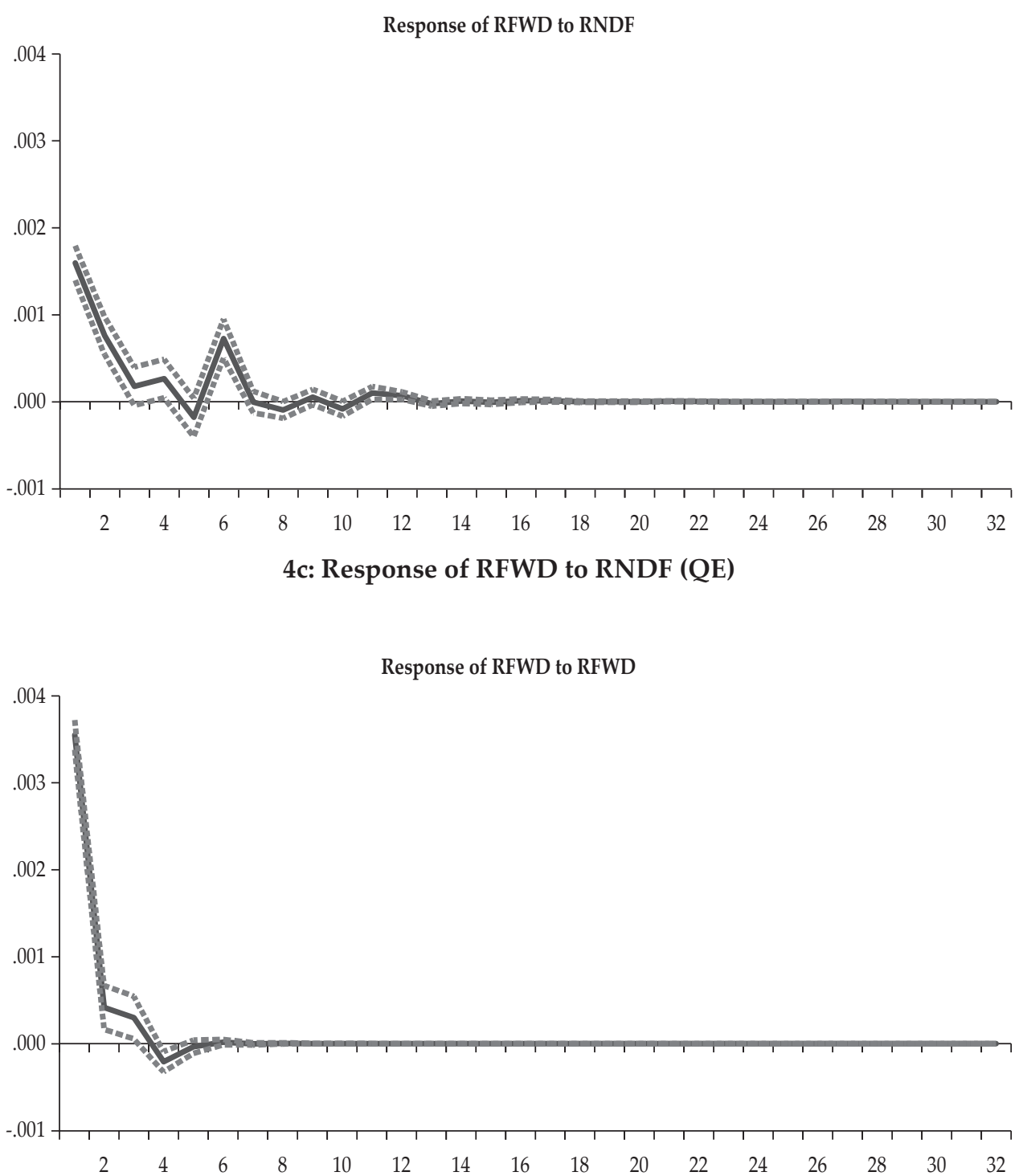

4d: Respond of RFWD to RNDF (Post-QE)

Notably, a NDF depreciation shock leads to an initial positive response from the spot rate in the pre- and post-QE period (see Figures $4 \mathrm{a}$ and $4 \mathrm{~b}$ ), implying a depreciation of the IDR. Furthermore, the initial depreciation of the IDR in the post-QE period is higher than during the QE period. This means that the NDF exerts more significant depreciation pressures on the IDR spot rate in the post-QE period. This is due to strict convertibility of the rupiah, compelling investors to use the NDF for hedging purposes when the market is very uncertain. 
Likewise, a depreciation shock in the NDF rate also leads to an initial positive response from the forward rate in both the pre- and post-QE period (see Figures 4c and $4 \mathrm{~d}$ ). Similarly, following the NDF shock, the forward rate of the IDR exhibits a higher depreciation during the post-QE period.

These results support hypotheses 1 and 2, namely that there is a strong unidirectional causality from NDF to the spot rate and from NDF to the forward rate in the post-QE period. Moreover, these results are consistent with the argument put forth by Kong and Shao (2010) and Maziad and Kang (2012)

A possible extension of our models is to incorporate the COVID-19 pandemic effects following recent work on exchange rates from Narayan et al. (2020), Narayan (2020b, c), Iyke (2020). ${ }^{2}$ We leave this for future research.

\section{CONCLUSION}

This study used daily and monthly data to explore the dynamic relationship between the dollar-rupiah NDF, spot, and forward rates over the pre- and postQE periods. Our study revealed some important findings. Based on daily data on the spot, forward, and NDF dollar-rupiah exchange rates from November 2010 to February 2018, we found the following. First, bidirectional causality exists between the NDF and spot rates, and the spot and forward rates during the US QE period. Second, there is a unidirectional causality from the NDF to forward rates. Third, there is a robust unidirectional causal flow from the NDF to the spot dollarrupiah exchange rates during the post-QE exit period. One possible explanation for this finding is that the predictive power of NDF over the spot exchange rate increases during the post-QE exit because of the hedging mechanism adopted by investors. Fourth, our results are different from the literature because our analysis considered international reserves and yields on government securities to explore the information transmitted to the NDF, forward, and the spot dollar-rupiah exchange rates during the pre- and post-QE periods.

Our results indicate that yields on government securities play a vital role in the spot, forward, and the NDF dollar-rupiah exchange rate movements in the US QE period. Moreover, international reserves provide a feedback to spot, forward, and NDF dollar-rupiah exchange rate in the post-QE exit period. We found that our main traditional VAR results are robust using the Toda-Yamamoto causality test.

Our findings have two important policy implications. First, since the study revealed that a depreciation shock to NDF exerts a higher depreciation pressure on the dollar-rupiah spot and forward rates. Therefore, a regulation of the trading activities in the offshore NDF market is needed to prevent a further drop in the rupiah value. Second, the study discovered that foreign reserves are the key to offsetting depreciation pressures on the rupiah post-QE. Therefore, the BI should closely monitor its international reserves to improve investor confidence in the rupiah.

2 There is a growing literature on COVID-19 and some of the studies that are likely to have messages for our hypothesis include (but are not limited to): see Devpura and Narayan (2020); Haroon and Rizvi (2020); Iyke (2020a,b); Mishra et al. (2020); Narayan (2020a); Narayan, Phan, and Liu (2020); Phan and Narayan (2020); Prabheesh et al. (2020); Rath, and Akram (2020); Salisu and and Akanni (2020); Vidya and Prabheesh (2020); and Salisu and Sikiru, (2020); among others. 


\section{REFERENCES}

Ahmad, R., Rhee, S.G. \& Wong, Y.M. (2012). Foreign exchange market efficiency under recent crises: Asia-Pacific focus. Journal of International Money and Finance, 31, 1574-1592.

Ahmed, S. \& Zlate, A. (2014). Capital flows to emerging market economies: A brave new world? Journal of International Money and Finance, 48, 221-248.

Alpanda, S., \& Kabaca, S. (2019). International Spillovers of Large-Scale Asset Purchases. Journal of the European Economic Association. https://doi.org/10.1093/ jeea/jvy053

Anstey, C. \& Miller, R. (2018). Emerging markets meet tighter money. Serial online, https://www.bloomberg.com/news/articles/2018-09-13/emerging-marketsmeet-tighter- money. Accessed 7 November 2018.

Apergis, E., \& Apergis, N. (2020). Can the COVID-19 pandemic and oil prices drive the US Partisan Conflict Index?. Energy Research Letters, 1, 13144. https:// doi.org/10.46557/001c.13144

Baba, N., \& Packer, F. (2009). From Turmoil to the Crisis: Dislocation in the Fx Swap Market Before and After the Failure of Lehman Brothers. Journal of International Money and Finance, 28, 1350-1374.

Basri, M,C. and Rahardja, S. (2010). The Global Financial Crisis and Asian Economies. ASEAN Economic Bulletin, 27, 77-97.

Bauer, M. D. and Neely, C. (2014). International Channels of the Fed's Unconventional Monetary Policy. Journal of International Money and Finance, 44, 24-46.

Bhattarai, S., Chatterjee, A. \& Park, W. Y. (2018). Effects of U.S. Quantitative Easing on emerging market economies (Working Paper No. 803). Asian Development Bank Institute.

Bhattarai, S. and Neely, C. (2016). A Survey of the Empirical Literature on US Unconventional Monetary Policy (Working Paper 2016-021A). Federal Reserve Bank of St. Louis, St. Louis, MO, USA.

Cadarajat, Y. \& Lubis, A. (2012). Offshore and Onshore IDR Market: An Evidence on Information Spillover. Bulletin of Monetary Economics and Banking, 14, 323347.

Chen, Y.C. and Tsang, K.P. (2013). What Does the Yield Curve Tell Us about Exchange Rate Predictability? Review of Economics and Statistics, 95, 185-205.

Cheng, A-R., Das, K. and Shimatani, T. (2013). Central bank intervention and exchange rate volatility: Evidence from Japan using realized volatility. Journal of Asian Economics, 28, 87-98.

Clarida, R.H. and Taylor, M.P. (1997). The Term Structure of Forward Exchange Premiums and the Forecastability of Spot Exchange Rates: Correcting the Errors. Review of Economics and Statistics, 79, 353-361.

Della Corte, P., Sarno, L. and Tsiakas, I. (2011). Spot and forward volatility in foreign exchange. Journal of Financial Economics, 100, 496-513.

Devpura, N., \& Narayan, P.K., (2020) Hourly oil price volatility: The role of COVID-19, Energy Research Letters, 1, 13683. https://doi.org/10.46557/001c.13683

Dominguez, K. and Frankel, J. (1993). Does Foreign Exchange Intervention Matter? The Portfolio Effect. American Economic Review, 83, 1356-1369. 
Engle, R. \& Granger, C. (1987). Co-integration and error correction: Representation, estimation, and testing. Econometrica, 55, 251-276.

Ertugrul, H.M., Gungor, B.O., and Soytas, U. (2020). Effect of COVID-19 Outbreak On Turkish Diesel Consumption Volatility Dynamics, Energy Research Letters, 1. https://doi.org/10.46557/001c.17496

Fatum, R. and Yetman, J. (2017). Does the Accumulation of Foreign Currency Reserves Affect Risk-Taking? An Event Study Approach (Working Paper No. 96). Bank for International Settlements.

Fratzscher, M., Duca, M.L., and Straub, R. (2016). On the International Spillovers of US Quantitative Easing. The Economic Journal, 128, 330-377.

Fu, M., \& Shen, H. (2020). COVID-19 and Corporate Performance in the Energy Industry. Energy Research Letters, 1, 12967. https://doi.org/10.46557/001c.12967

Gil-Alana, L. A., \& Monge, M. (2020). Crude Oil Prices and COVID-19: Persistence of the Shock. Energy Research Letters, 1, 13200. https://doi.org/10.46557/001c.13200

Guru, A. (2009). Non-Deliverable Forwards Market for Indian Rupee: An Empirical Study. Indian Journal of Economics and Business, 8, 245-260.

Higgins, P. \& Humpage, O.F. (2005). Nondeliverable Forwards: Can We Tell Where the Renminbi Is Headed? (Working Paper). Federal Reserve Bank of Cleveland.

Huang, W., \& Zheng, Y. (2020). COVID-19: Structural Changes in the Relationship Between Investor Sentiment and Crude Oil Futures Price. Energy Research Letters, 1, 13685. https://doi.org/10.46557/001c.13685

Indonesia Investments. (2015a). Why is Indonesia's Rupiah Weakening? Global \& domestic factors.Accessed on 12 May 2018.

Indonesian Investments. (2015b). Policy Package Bank Indonesia to Safeguard Rupiah Stability and Enhance Management. Accessed on 17 November 2018.

Indonesia Investments. (2015c). Indonesian Rupiah is Persistently Depreciating against the U.S. Dollar. Accessed 17 November 2018.

Ishii, S., Otker-Robe, I \& Li, C. (2001). Measures to Limit the Offshore Use of Currencies: Pros and Cons (Working Paper No. 01/43). International Monetary Fund.

Iyke, B. N. (2019). A Test of the Efficiency of the Foreign Exchange Market in Indonesia. Buletin Ekonomi Moneter dan Perbankan, 21, 439-464.

Iyke, B., (2020a) COVID-19: The Reaction Of US Oil And Gas Producers To The Pandemic. Energy Research Letters, 1, 13912. https://doi.org/10.46557/001c.13912

Iyke, B.N., (2020b) The Disease Outbreak Channel of Exchange Rate Return Predictability: Evidence from COVID-19. Emerging Markets Finance and Trade, 56, 2277-2297; https://doi.org/10.1080/1540496X.2020.1784718

Izawa, H. (2006). An Empirical Test of the Efficiency Hypothesis on the Renminbi NDF in the Hong Kong market (Discussion Paper Series No. 196). Kobe University.

Juhro, S. M., \& Iyke, B. N. (2019). Monetary Policy and Financial Conditions in Indonesia. Buletin Ekonomi Moneter dan Perbankan, 21, 283-302.

Kim, S-J., Kortian, T., \& Sheen, J. (2000). Central Bank Intervention and Exchange Rate Volatility- Australian evidence. Journal of International Financial Markets, Institutions and Money, 10, 381-405.

Kong, L.L., \& Shao, W.Y. (2010). An empirical study on the relationship between NDF and DF. 2010 The $2^{\text {nd }}$ IEEE International Conference Proceedings, 495-499.

Kwiatkowski, D., Philips, P.C.B., Schmidt, P., \& Shin, Y. (1992). Testing the null hypothesis of stationarity against the alternative of a unit root. Journal of Econometrics, 54, 159-178. 
Lei, G., \& Yulan, D. (2016). Research on the correlation between onshore and offshore RMB markets. International Conference on Service Systems and Service Management (ICSSSM, 2016).

Liu, L., Wang, E. Z., \& Lee, C. C. (2020). Impact of the COVID-19 Pandemic On The Crude Oil and Stock Markets in the US: A Time-Varying Analysis. Energy Research Letters, 1, 13154. https://doi.org/10.46557/001c.13154

Maziad, S., \& Kang, J. (2012). RMB Internationalization Onshore/Offshore Links (Working Paper No. 12/133). International Monetary Fund.

Mishkin, F.S. (2016). The Economics of Money, Banking and Financial markets, Global Edition. Printed in Malaysia: Pearson.

Misra, S., \& Behera, H. (2006). Non-deliverable foreign exchange forward market: An overview. Reserve Bank of India Occasional Paper, 27, 25-55.

Neely, Christopher J. (2015). Unconventional Monetary Policy had Large International Effects. Journal of Banking E Finance, 52, 101-111.

Nangoy, F. (2018). Indonesia's Plan to Create a Domestic Rupiah NDF Market. Reuters Business News. (Retrieved on 1 Nov 2019).

Narayan, P. K. (2020a). Oil price news and COVID-19-Is there any connection? Energy Research Letters, 1, 13176. https://doi.org/10.46557/001c.13176

Narayan, P. K. (2020b). Did Bubble Activity Intensify During COVID-19? Asian Economics Letters, 1. https://doi.org/10.46557/001c.17654.

Narayan, P. K. (2020c). Has COVID-19 Changed Exchange Rate Resistance to Shocks? Asian Economics Letters, 1. https://doi.org/10.46557/001c.17389

Narayan, P. K., Devpura, N., \& Hua, W. (2020). Japanese Currency and Stock Market-What Happened During the COVID-19 Pandemic? Economic Analysis and Policy, 68, 191-198.

Narayan, P. K., Phan, D. H. B., \& Liu, G. (2020). COVID-19 Lockdowns, Stimulus Packages, Travel Bans, And Stock Returns. Finance Research Letters, 101732. https://doi.org/10.1016/j.frl.2020.101732.

Narayan, P.K., \& Popp, S. (2010). A new unit root test with two structural breaks in level and slope and unknown time. Journal of Applied Statistics, 37, 1425-1438.

Ooi, T.K., \& Lau, W.Y. (2020). Impact of Market Expectations on the U.S. Interest Rate Lift-Off in ASEAN-5 Financial System. Asia-Pacific Financial Markets. https://doi.org/10.1007/s10690-020-09314-4

Park, J. (2001). Information flows between non-deliverable forwards (NDF) and spot markets: Evidence from Korean currency. Pacific-Basin Finance Journal, 9, 363-377.

Phan, D.H.B., \& Narayan, P.K., (2020) Country Responses and the Reaction of the Stock Market to COVID-19-a Preliminary Exposition, Emerging Markets Finance and Trade, 56, 2138-2150; https://doi.org/10.1080/1540496X.2020.1784719

Prabheesh, K.P., Padhan, R., \& Garg, B. (2020). COVID-19 and the Oil Price-Stock Market Nexus: Evidence from Net Oil-Importing Countries. Energy Research Letters, 1, 13745. https://doi.org/10.46557/001c.13745.

Qin, M., Zhang, Y. C., \& Su, C. W. (2020). The Essential Role of Pandemics: A Fresh Insight into the Oil Market. Energy Research Letters, 1, 13166. https://doi. org/10.46557/001c.13166

Rajakaruna, S.H.I. (2017). An Investigation on Factors Affecting Exchange Rate Fluctuations in Sri Lanka. Staff Studies, 47, 69-100. 
Ren, S. (2015). Sizing Indonesia's Capital Outflow: The Worst Is Yet To Come? Serial online https://www.barrons.com/articles/sizing-indonesias-capitaloutflow-the-worst-is-yet-to-come-1442381812. Accessed 17 November 2018

Salisu, A., \& Adediran, I. (2020). Uncertainty due to infectious diseases and energy market volatility Energy Research Letters, 1, 14185. https://doi. org/10.46557/001c.14185

Salisu, A. A., \& Sikiru, A. A. (2020) Pandemics and the Asia-Pacific Islamic stocks. Asian Economics Letters, 1. https://doi.org/10.46557/001c.17413

Sims, C. A., Stock, J. H., \& Watson, M. W. (1990). Inference in Linear Time Series Models with Some Unit-Roots. Econometrica, 58, 113-144.

Suhartono, H., \& Carson, R. (2018). Bank Indonesia Has More Work To Do. Serial online https://www.pressreader.com/thailand/bangkokpost/20180521/282093457395994. Accessed 18 November 2018.

Takumah, W., \& Iyke, B. N. (2017). The Links Between Economic Growth And Tax Revenue In Ghana: An Empirical Investigation. International Journal of Sustainable Economy, 9, 34-55.

Toda, H. Y., \& Yamamoto, T. (1995). Statistical Inference in Vector Autoregression with Possibly Integrated Processes. Journal of Econometrics, 66, 225-250.

Wang, K.L., Fawson, C., Chen, M.L. and Wu, A.C. (2014). Characterising Information Flows Among Spot, Deliverable Forward and Non-Deliverable Forward Exchange Markets: A Cross-Country Comparison. Pacific-Basin Finance Journal, 27, 115-137. 